\title{
Central Corneal Thickness in Females Using Oral Contraceptive Pills
}

\author{
Samia Igbal ${ }^{1}$, Khizar Bashir ${ }^{2}$, Minahal Mateen ${ }^{3}$, Mateen Amir ${ }^{4}$, Iftikhar Ahmad ${ }^{5}$ \\ 1,2,4,5 University of Lahore Teaching Hospital, ${ }^{3}$ Services Hospital-Lahore
}

\begin{abstract}
Purpose: To compare the central corneal thickness in females using oral contraceptive pills (OCP) with age matched controls.

Study Design: Descriptive Observational study.

Place and Duration of Study: Department of Ophthalmology, University of Lahore teaching hospital, from August 2018 to December 2018.

Material and Methods: Fifty-one females who used OCP within last one year and 38 age-matched controls were included in this study after approval from the ethical review board. Females with any systemic disease, pregnancy and lactating mothers were excluded from the study. Females with ocular diseases, like trachoma, cataract, keratitis, uveitis, corneal dystrophies, Keratoglobus, Keratoconus, ocular trauma, and high refractive errors were also excluded. Each subject underwent full ocular examination including best-corrected visual acuity using Snellen acuity chart and Bio-microscopic examination of anterior segment and the fundus. Central corneal thickness (CCT) was measured with ultrasonic pachymeter and the intraocular pressure was measured with noncontact tonometer at the time of examination. The data was collected by self-designed proforma and analyzed by using SPSS version 20.
\end{abstract}

Results: Mean age of the females using OCP was $31.4 \pm 6.8$ years and mean age of age-matched controls was $32.9 \pm 5.5$ years $(p=0.38)$. Mean Central corneal thickness values were higher in OCP group when compared to controls $(541.8 \pm 31.39 \mu \mathrm{m}$ and $518.7 \pm 36.7 \mu \mathrm{m}$, respectively). $\mathrm{P}$ value was 0.004 , which was statistically significant. The mean IOP value was $14.5 \pm 2.6 \mathrm{~mm} \mathrm{Hg}$ in OCP group and $14.4 \pm 2.8 \mathrm{~mm} \mathrm{Hg}$ in the control group $(P=0.86)$, which was not statistically significant.

Conclusion: Central corneal thickness values are significantly higher in patients using OCP.

Key Words: Oral Contraceptive pills, Central corneal thickness, Intraocular pressure.

How to Cite this Article: Iqbal S, Bashir K, Mateen M, Amir M, Ahmad I. Central Corneal Thickness in Females Using Oral Contraceptive Pills, Pak J Ophthalmol. 2020; 36 (1): 29-32.

DOI: https://doi.org/10.36351/pjo.v36i1.916

\section{INTRODUCTION}

An average cornea is between $540 \mu \mathrm{m}$ and $560 \mu \mathrm{m}$ thick. A thick cornea is $565 \mu \mathrm{m}$ or more and a very thick cornea being greater than $600 \mu \mathrm{m} .{ }^{1}$

Address for Correspondence: Samia Iqbal

Doctor of Optometry,

University of Lahore Teaching Hospital, Lahore

Email: samiaiqbal988@gmail.com
Measuring Central corneal thickness (CCT) is important for numerous ophthalmic procedures including refractive surgery. Corneal thickness variations are seen in Keratoconus and after long-term use of contact lens. ${ }^{2}$

Use of the oral contraceptive pills (OCPs) is common during reproductive years ${ }^{3}$. The hormone known as Gonadotropin play a role in corneal diseases and in females the central corneal thickness may be affected by female hormones. Studies have shown that 
Central Corneal Thickness in Females Using Oral Contraceptive Pills

hormonal changes during oral contraceptive pill (OCP) use may affect central corneal thickness (CCT) ${ }^{4}$.

Numerous data exist to describe the manifestation of a diversity of ocular diseases in females using $(\mathrm{OCPs})^{5,6}$. However, the consequences of gonadotropin and ovarian hormones on corneal biomechanics are uncertain. In this study, we tried to find out association between oral contraceptive pills and central corneal thickness (CCT).

\section{MATERIAL AND METHODS}

It was comparative observational study. We examined fifty-one young women using OCP who visited the eye department for a routine ocular examination. Thirtyeight controls not using OCP or not having used any form of hormonal birth control, at any period of their life were also included in the study. All the subjects having any other systemic disease were excluded from the study. Pregnant and lactating women were also not included in either group. Subjects having ocular problems like trachoma, cataract, keratitis, uveitis and corneal issues like keratoglobus and keratoconus, trauma and high refractive errors were excluded from the study.

Each subject underwent full ocular examination including best-corrected visual acuity using Snellen visual acuity chart and bio-microscopic examination of anterior segment and retina. The ultrasonic Pachymeter was used to measure CCT and the intraocular pressure was measured with non-contact tonometer at the time of examination.

\section{RESULTS}

The mean ages were $32.9 \pm 5.5$ years for control group and $31.4 \pm 6.8$ years for OCP group $(P=0.38)$. Mean Central corneal thickness values were significantly higher in OCP group as compared to that of the control group $(541.8 \pm 31.39 \mu \mathrm{m}$ and $518.7 \pm 36.7 \mu \mathrm{m}$, respectively) $(P=0.004)$. The mean IOP value was $14.4 \pm 2.8 \mathrm{~mm} \mathrm{Hg}$ in control group and $14.5 \pm 2.6 \mathrm{~mm}$ $\mathrm{Hg}$ in OCP group $(P=0.86)$. Further details are depicted in tables 1 and 2 .

Table 1: Age Distribution in Subjects Using Contraceptive Pills and Controls.

\begin{tabular}{|c|c|c|c|c|}
\hline$\overline{\text { OCP GROUP }}$ & & & & \\
\hline & Frequency & Percent & $\begin{array}{l}\text { Valid } \\
\text { Percent }\end{array}$ & $\begin{array}{l}\text { Cumulative } \\
\text { Percent }\end{array}$ \\
\hline Valid $20-30$ & 28 & 54.9 & 54.9 & 54.9 \\
\hline
\end{tabular}

\begin{tabular}{|c|c|c|c|c|c|}
\hline & $31-40$ & 14 & 27.4 & 27.4 & 45.1 \\
\hline & $41-45$ & 9 & 17.6 & 17.6 & 100.0 \\
\hline & Total & 51 & 100.0 & 100.0 & \\
\hline $\mathrm{CON}^{\prime}$ & ROL C & OUP & & & \\
\hline & & Frequency & Percent & $\begin{array}{l}\text { Valid } \\
\text { Percent }\end{array}$ & $\begin{array}{l}\text { Cumulative } \\
\text { Percent }\end{array}$ \\
\hline & $20-30$ & 24 & 63.1 & 63.1 & 54.9 \\
\hline Yolid & $31-40$ & 8 & 21.0 & 21.0 & 84.1 \\
\hline Valid & $41-45$ & 6 & 15.7 & 15.7 & 100.0 \\
\hline & Total & 38 & 100.0 & 100.0 & \\
\hline
\end{tabular}

Table 2: Comparison between the two groups.

\begin{tabular}{ccccc}
\hline \multicolumn{6}{l}{ Variables } & Control Group & OCP Group & P Value \\
\hline & Age & $(20-45)$ & $(20-45)$ & 0 \\
& (Years) & $32.9 \pm 5.5$ & $31.4 \pm 6.8$ & \\
Valid & CCT & $\begin{array}{c}541.8 \pm 31.39 \\
(480-625)\end{array}$ & $\begin{array}{c}518.7 \pm 36.7 \\
(430-572)\end{array}$ & 0.004 \\
& & $\begin{array}{c}14.4 \pm 2.8 \\
(9.7-21.4)\end{array}$ & $\begin{array}{c}14.5 \pm 2.6 \\
(9.2-21.1)\end{array}$ & \multirow{2}{*}{0.86} \\
\hline
\end{tabular}

$\mathrm{OCP}=$ oral contraceptive pills

$\mathrm{CCT}=$ Central corneal thickness

$\mathrm{IOP}=$ Intraocular pressure

\section{DISCUSSION}

Many Studies have been done to see the possible association between central corneal thickness and the levels of hormones throughout oral contraceptive pills use in young females. ${ }^{7,8}$ Recent study suggested that an increase has been noted in the use of contraceptive pills for contraception in females of reproductive age group $^{9,10}$.

In this study, our findings revealed that CCT values were significantly higher in patients with OCP use. OCP use is not only associated with drastic ocular diseases like retinal vascular occlusions but there are other studies showing that the central corneal thickness and Intraocular pressure were also affected by the use of $\mathrm{OCP}^{11,12}$. Oral contraceptive pills affect the central corneal thickness and Intraocular pressure which erroneously make these females as glaucoma suspects ${ }^{13}$.

The duration of OCP use is also an important factor. However, the American Academy of Ophthalmology, in New Orleans, came out with a research stating that women having these pills for three years or more are facing double the risk of developing glaucoma, which is one of the leading causes of blindness. Contrary to that, a recent study in Pakistan indicated that OCP even if used for six months to one year causes a statistically significant increase in IOP (although not clinically significant) ${ }^{14}$. 
The Central corneal thickness appears to increase around ovulation until the completion of menstrual cycle. The central corneal thickness changes in the midst of the menstrual cycle as the cornea is most thin toward the beginning of the cycle and thickest toward the end ${ }^{15,16}$. This can be attributed to the presence of estrogen receptors in human corneas. ${ }^{17}$ In another study, cornea seemed to be thickest either at the beginning or the end of the menstrual cycle because of the variation in ovarian and gonadotropin hormones ${ }^{18}$.

Although Oral contraceptive use does not appear to increase the risk of eye diseases such as conjunctivitis, keratitis, iritis, lacrimal disease, strabismus, cataract, glaucoma and retinal detachment but there is some evidence that OCP use was found to be a risk factor for retinal vascular occlusion in invitro fertilization patients ${ }^{19}$. Hormonal changes occurring regularly during gestation may also have a severe impact on the progression of keratoconus ${ }^{20}$. Hence, females using OCP must be warned of the possible complications of these medicines and CCT must be considered while measuring IOP in these patients.

\section{CONCLUSION}

Our findings revealed that Central corneal thickness values were significantly higher in patients using OCPs.

\section{Ethical Approval}

The study was approved by the Institutional review board/Ethical review board.

\section{Conflict of Interest}

Authors declared no conflict of interest

\section{Authors' Designation and Contribution}

Samia Iqbal; Doctor of Optometry: Study design, data collection, analysis, manuscript writing and final review.

Khizar Bashir; Head of Department, Optometry and Vision Sciences: Data collection, analysis and final review.

Minahal Mateen: Medical Officer: Study design and final review.

Mateen Amir; Professor of Ophthalmology: Study design and final review.
Iftikhar Ahmad; Assistant Professor: Study design and final review.

\section{REFERENCES}

1. Wong AC, Wong CC, Yuen NS, Hui SP. Correlational study of central corneal thickness measurements on Hong Kong Chinese using optical coherence tomography, Orbscan and ultrasound pachymetry. Eye (Lond), 2002; 16 (6): 715-21.

2. Ondas O, Keles S. Central corneal thickness in patients with atopic keratoconjunctivitis. Med Sci Monit. 2014; 20: 1687-90. Doi:10.12659/MSM.890825.

3. Daniels $\mathbf{K}$, Daugherty J, Jones J. Current contraceptive status among women aged 15-44: United States, 2011-2013. NCHS Data Brief. 2014; 173: 1-8.

4. Vessey MP, Hannaford P, Mant J, Painter R, Frith $\mathbf{P}$, Chappel D. Oral contraception and eye disease: Findings in two large cohort studies. Br J Ophthalmol. 1998; 82 (5): 538-42.

5. Kawase K, Tomidokoro A, Araie M, Iwase A, Yamamoto T. Tajimi Study Group; Japan Glaucoma Society. Ocular and systemic factors related to intraocular pressure in Japanese adults: The Tajimi study. Br J Ophthalmol. 2008; 92 (9): 1175-9.

6. Su DH, Wong TY, Foster PJ, Tay WT, Saw SM, Aung T. Central corneal thickness and its associations with ocular and systemic factors: The Singapore Malay Eye Study. Am J Ophthalmol. 2009; 147 (4): 709716.e1.

7. Westhoff CL, Torgal AH, Mayeda ER, Stanczyk FZ, Lerner JP, Benn EK, et al. Ovarian suppression in normal-weight and obese women during oral contraceptive use: A randomized controlled trial. Obstet Gynecol. 2010; 116 (2 Pt 1): 275-83.

8. Leske MC, Heijl A, Hyman L, Bengtsson B, Dong L, Yang Z. EMGT Group. Predictors of long-term progression in the early manifest glaucoma trial. Ophthalmology, 2007; 114 (11): 1965-72.

9. Giuffrè G, Di Rosa L, Fiorino F, Bubella DM, Lodato G. Variations in central corneal thickness during the menstrual cycle in women. Cornea, 2007; 26 (2): 144-6.

10. Soni PS. Effects of oral contraceptive steroids on the thickness of human cornea. Am J Optom Physiol Opt. 1980; 57 (11): 825-34.

11. Stojanov O, Stokic E, Sveljo O, Naumovic N. The influence of retrobulbar adipose tissue volume upon intraocular pressure in obesity. Vojnosanit Pregl. 2013; 70 (5): 469-76.

12. Mori K, Ando F, Nomura H, Sato Y, Shimokata $H$. Relationship between intraocular pressure and obesity in Japan. Int J Epidemiol. 2000; 29 (4): 661-6.

13. Zafra Pérez JJ, Villegas Pérez MP, Canteras Jordana M, Miralles De Imperial J. Intraocular 
pressure and prevalence of occult glaucoma in a village of Murcia. Arch Soc Esp Oftalmol. 2000; 75 (3): 1718.

14. Malik TG, Nadeem H, Ayesha E, Alam R. Effect of Short-term Use of Oral Contraceptive Pills on Intraocular Pressure. Pak J Ophthalmol 2019; 35 (3): 184-87. DOI: https://doi.org/10.36351/pjo.v35i3.966.

15. Sen E, Onaran Y, Nalcacioglu-Yuksekkaya P, Elgin U, Ozturk F. Corneal biomechanical parameters during pregnancy. Eur J Ophthalmol. 2014; 24(3): 314-9.

16. Abramov Y, Borik S, Yahalom C, Fatum M, Avgil G, Brzezinski A, et al. Does postmenopausal hormone replacement therapy affect intraocular pressure? J Glaucoma, 2005; 14 (4): 271-5.
17. Dong SY, Si YB, Zhang YY, Zhao GM. Risk factors analysis of primary open angle glaucoma in women. Zhonghua Yan Ke Za Zhi. 2013; 49 (2): 122-5.

18. Paterson GD, Miller SJ. Hormonal influence in simple glaucoma. A preliminary report. $\mathrm{Br} \mathrm{J}$ Ophthalmol. 1963; 47: 129-37.

19. Kass MA, Sears ML. Hormonal regulation of intraocular pressure. Surv Ophthalmol. 1977; 22 (3): $153-76$.

20. Aggarwal RS, Mishra VV, Aggarwal SV. Oral contraceptive pills: A risk factor for retinal vascular occlusion in in-vitro fertilization patients. J Hum Reprod Sci. 2013; 6 (1): 79-81. 